\title{
Eugene Vorobieva
}

PhD in Pedagogy, Associate Professor at Pedagogy and Psychology of Social Systems Management Department of the academician I. A. Ziaziuna, National Technical University

"Kharkiv Polytechnic Institute"; Kharkiv, Ukraine

ORCID: 0000-0002-6269-578X

E-mail: evorobjova@ukr.net

\section{Yulia Chebakova}

PhD in Pedagogy, Associate Professor at Pedagogy and Psychology of Social Systems Management Department of the academician I. A. Ziaziuna, National Technical University

"Kharkiv Polytechnic Institute"; Kharkiv, Ukraine

ORCID: 0000-0001-9317-8585

E-mail: ch-julia2@rambler.ru

\section{ORGANIZATION OF THE EDUCATIONAL PROCESS IN A MODERN HIGHER EDUCATION INSTITUTION BASED ON A FACILITATIVE APPROACH}

Abstract: the article elucidates the peculiarities of reforming the educational process in institutions of higher education and defines the relevance of the activities of the modern teacher of institution of higher education institution as a facilitator; analyzes and summarizes the features of the implementation facilitative approach in the educational space of the modern HEI; the publication contains generalizations and conclusions about the content and peculiarities of implementation facilitating approach in the professional activities of scientific and pedagogical workers of HEI. approach.

Key words: educational process; modern higher education institution; facilitative

\section{Свгенія Воробйова}

кандидат педагогічних наук, доцент кафедри педагогіки і психології управління соціальними системами ім. академіка I. А. Зязюна, Національного технічного університету “Харківський політехнічний інститут”; Харків, Україна

ORCID: 0000-0002-6269-578X

E-mail:evorobjova@ukr.net

\section{Юлія Чебакова}

кандидат педагогічних наук, доцент кафедри педагогіки і психології управління соціальними системами ім. академіка I. А. Зязюна, Національного технічного університету "Харківський політехнічний інститут”; Харків, Україна

ORCID: 0000-0001-9317-8585

E-mail: ch-julia2@rambler.ru

(C) Eugene Vorobieva, Yulia Chebakova, 2020 


\section{ОРГАНИЗАЦІЯ ОСВІТНЬОГО ПРОЦЕСУ В СУЧАСНОМУ ЗАКЛАДІ ВИЩОЇ ОСВІТИ НА ЗАСАДАХ ФАСИЛІТАТИВНОГО ПІДХОДУ}

Анотація: в статті висвітлено особливості реформування освітнього процесу у закладах вищої освіти; визначено актуальність діяльності сучасного викладача закладу вищої освіти як фасилітатора; проаналізовано та узагальнено особливості впровадження фасилітативного підходу в освітній простір сучасних 3ВО; публікація містить узагальнення та висновки щодо змісту та особливостей впровадження фасилітативного підходу в професійній діяльності науково-педагогічних працівників 3ВО.

Ключові слова: освітній процес; сучасний заклад вищої освіти; фасилітативний підхід.

\section{Евгения Воробьёва, Юлия Чебакова}

\section{ОРГАНИЗАЦИЯ ОБРАЗОВАТЕЛЬНОГО ПРОЦЕССА В СОВРЕМЕННОМ УЧРЕЖДЕНИИ ВЫСШЕГО ОБРАЗОВАНИЯ НА ОСНОВЕ ФАСИЛИТАТИВНОГО ПОДХОДА}

Аннотащия: в статье освещены особенности реформирования образовательного процесса в учреждениях высшего образования; определена актуальность деятельности современного преподавателя учреждения высшего образования как фасилитатора; проанализированы и обобщены особенности внедрения фасилитативного подхода в образовательное пространство современных УВО; публикация содержит обобщения и выводы относительно содержания и особенностей внедрения фасилитативного подхода в профессиональной деятельности научно-педагогических работников УВО.

Ключевые слова: образовательный процесс; современное учреждение высшего образования; фасилитативний подход.

\section{Свгенія Воробйова, Юлія Чебакова}

Розширена анотація для ознайомлення $з$ цією темою:

“Организація освітнього процесу в сучасному закладі вищої освіти на засадах фасилітативного підходу"

Постановка проблеми в загальному вигляді та ї̈ зв'язок із важливими науковими чи практичними завданнями. Актуальність досліднищької проблеми обумовлена тим, щчо, незважаючи на зміни в суспільстві, світі та кардинальні зміни потреб економіки, традициційні підходи до освіти залишилися в минулому. Однак сильна держава та конкурентна економіка можуть забезпечити згуртовану спільноту творчих людей, відповідальних громадян, активних та підприємливих. Це типи студентів, які повинні готувати середні та вищі школи. У зв'язку з циим розпочато системну трансформацію галузі освіти, основні положення якої викладені в таких політичних документах, як "Реформа освіти та науки" та "Стратегія реформування вищої освіти в Україні". Основна мета реформ - нова високоякісна освіта на всіх рівнях: від початкової школи до вищих навчальних закладів. Відповідно до иих документів, зміст професійно-технічної та вищої освіти повинен постійно оновлюватися з урахуванням потреб підприємств - замовників кадрів. Особливо актуальним є питання мобільності, конкурентоспроможності та рівня кваліфікації працівників. Освітній та науковий сектори мають стати важелем соиіальної рівності 
та згуртованості, економічного розвитку та конкурентоспроможності Украӥни.

Тому прочес трансформаціï в освітній сфері України охоплюе всі рівні від початкових до вищзих навчальних закладів.

Ця ситуація, в свою чергу, говорить про актуальність оновленої ролі викладача вищих навчальних закладів як фасилітатора.

Аналіз останніх досліджень $\boldsymbol{i}$ публікацій, у яких започатковано розв'язання иієї проблеми $i$ на які спирається автор. Проблема сприяння взаємодіі викладача та студента вивчалась у своїх дослідженнях Н. Бочкарьова, О. Галицан, О. Гнатишина, P. Димухаметов, Н. Дзюбак, О. Козіна, О. Кондрашихіна, О. Майєр, С. Ромашина, Л. Тимоніна, Б. Яковлев. Проблема якості сучасного навчально-виховного процесу досліджується у роботах В. Андрушенка, I. Беха, К. Гнезділової, О. Демченко, В. Зінченка, М. Кисіля, К. Корсака, О. Левченка, В. Лугового, О. Романовського, П. Сауха, Й. Таланової, I. Тализіноі, А. Токман, М. Степко, Є. Шульгіна, С. Цимбалюк, Ю. Яхніна. Аналіз досліджень показує, щзо більшість наукових досліджень $i$ робіт присвячені фасилітаційній взаємодії в системі «викладач-студент», тоді як проблема ролі вчителя-фасилітатора як важливої для сучасного навчального прочесу не вивчалася у спеціальних педагогічних дослідженнях.

\section{Формулювання цілей}

(постановка завдання). cmammi Метою дослідження є визначення ролі та функиій викладача-фасилітатора для забезпечення високої якості навчального процесу в сучасних вищих навчальних закладах.

Виклад основного матеріалу досліджсенн 3 повним обгрунтуванням отриманих наукових результатів. Масштабні зміни, шуо відбуваються в Україні, вплинули насамперед на реформу освітньої системи та встановили нові вимоги до освіти у ХХІ столітті. Вона повинна бути пріоритетною, безперервною та різноманітною, нести гуманістичні ичнності, використовувати нові технологї навчання, бути всебічною mа інформативною, а головне забезпечувати саморозвиток особистості. Система освіти, ї̈ зміст та структура змінюються з розвитком суспільства відповідно до викликів сучасності. Необхідність таких змін викликана певними обставинами.

Навчальний прочес у сучасному університеті - ие комплексне, багатогранне заняття. Суспільство поклало на наукових $i$ педагогічних працуіників такі важливі завдання, як збереження та примноження культурної спадщчини нації, изілеспрямоване виховання молодого покоління, позитивна сочіалізачія та правильна орієнтація особистості на вирішальному етапі ї̈ формування, пов'язаному з отриманням вищуӧ професійної освіти .

Звичайно, викладач ВНЗ повинен мати навички організатора, оратора, аналітика, психолога; повинні володіти суворою логікою педагогічного прочесу та виховання, літературним усним і писемним мовленням. Однак вчитель повинен вміти говорити з молоддю «однією $і$ тією ж мовою».

Національна система освіти формується в умовах значних змін $у$ духовному просторі суспільства. Це вимагає від вчителів певних коректив цілей, завдань та змісту навчального процесу. Навчальний процес у вищуому навчальному закладі для молодої людини цуе період не лише активного набуття знань, пов'язаних із майбутньою професійною діяльністю, але й затвердження професійних пріоритетів та уподобань, остаточного формування ідеологічних настанов.

$$
\text { Навчальний прочес можна }
$$

визначити як інтелектуальну, творчу діяльність у галузі вищуої освіти та науки, яка здійснюеться у вищзоу навчальному закладі (науковому закладі) за допомогою системи науково-методичних та педагогічних заходів, спрямованих на передачу, розвиток тощз, збільшення та 
використання знань, умінь та навичок учнів, а також формування гармонійно розвиненої особистості.

Навчальний процес реалізується на основі таких принциипів: відкритість, доступність, наступність, незалежність від втручання будь-яких політичних партій, громадських та релігійних організацій, єдність наукової та освітньої діяльності тощуо.

На наш погляд, проиес навчання повинен обов'язково включати такий важливий елемент, як самоосвіта. Тому важливо $i$ актуально розглянути інновачійні підходи до процесу навчання, зокрема, фасилітативного підходу.

При фасилітативному підходi важливо визначити технологї та методи, які продуктивно впливають на якість підготовки майбутніх фахівців у різних галузях: метод проекту, вирішення проблем, дослідження, портфоліо, дебати, діалоги, імітаційні ігри, професійні завдання тощзо. інтерактивні технології навчання тощуо.

Використання фасилітативного підходу в навчальній практиці призводить до підвищення ефективності групової роботи, залучення та зачікавленості учасників, розкриття їхнього потенціалу.

Таким чином, використання фасилітативного підходу до підготовки майбу-

Problem setting. Its relation to important scientific and practical tasks. The relevance of the research problem is due to the fact that despite changes in society, the world, and fundamental changes in the needs of the economy, approaches to education have remained far in the last century. However, a strong state and a competitive economy can provide a cohesive community of creative people, responsible citizens, active and enterprising. These are the types of students that secondary and higher schools should prepare. The content of vocational and higher education should be constantly updated taking into account the needs of enterprises customers of personnel. The issue of mobility, competitiveness and the level of qualification of employees is particularly relevant. The тніх фахівиів у різних галузях сприяє розвитку професійного потенціалу, ідентичності, створює умови для розвитку фасилітативної компетентності, підвищує ефективність їхнього навчання та подальшой професійнӧ̈ діяльності. Фасилітатор підвищує ефективність навчання, насамперед за рахунок оптимізаизї процуесу співпраці в групах «викладач-студент» та «студент-студент». Важливими є форми та методи внутрішньої групової взаємодії: як учні спілкуються між собою, як знаходять спільне розуміння проблем, які рішення приймають та як вирішують конфлікти.

Висновки 3 даного дослідження та перспективи подальших розвідок $у$ даному напрямку. Проблема, яку ми вирішили, $\epsilon$ актуальною та значною $i$ потребуе подальшого дослідження. Зокрема, особлива увага приділяється методам фасилітації, детальному обтрунтуванню механізму їхньої дії ma впливу на особистість студента. Отже, фасилітація - ие ефективний інструмент, універсальна технологія, оволодіння якою значно покрашуе не тільки якість засвоєння дисииплін, а й загальну професійну та особистісну компетентність та продуктивність студентів за рахунок економії часу, ресурсів та творчих перспектив.

educational and scientific sectors should become a lever of social equality and cohesion, economic development and competitiveness of Ukraine. Therefore, the transformation process in the educational sphere of Ukraine covers all levels, from primary to higher education institutions.

The adoption of the framework law of Ukraine "On Education" [1] allowed the largescale reforms of the education system in Ukraine. The law defines the purpose of education as follows:

1. Comprehensive development of a human as a personality and the highest value of society, his talents, intellectual, creative and physical abilities; 
2. Formation of values and competencies necessary for successful selfrealization of the individual;

3. Up-bringing of responsible citizens who are capable of conscious public choice and direction of their activities for the benefit of other people and society as a whole;

4. Enriching the intellectual, economic, creative and cultural potential of the Ukrainian people, increasing the educational level of citizens to ensure the sustainable development of Ukraine and its European choice.

In the context of ongoing reforms in the system of national higher education, one of the most important tasks is to increase the level of professionalism of graduates, which is also due to the fact that with the continuous development of science and technology, the requirements for the level and quality of training of graduates are increasing.

This situation, in turn, suggests the relevance of the updated role of the teacher of higher education institutions as a facilitator.

Recent research and publications analysis. That started solving this problem and to which the author refers. The problem of facilitating interaction between the teacher and the student was studied in their researches N. Bochkaryova, O. Halitsan, O. Hnatyshina, R. Dimukhametov, N. Dzyubak, O. Kozina, O. Kondrashikhina, O. Mayer, S. Romashina, L. Timonina, B. Yakovlev. The problem of the quality of the modern educational process is investigated in the works of V. Andrushchenko, I. Bech, K. Gnezdilova, O. Demchenko, V. Zinchenko, M. Kisil, K. Korsak, O. Levchenko, V. Lugovoi, P.Saukh, J. Talanova, I. Talyzina, A. Tokman, M. Stepko, E. Shulgin, S. Tsymbalyuk, Y. Yakhnin.

Highlighting previously unsolved parts of the general problem that this article is devoted to. The analysis of the researches shows that most of the scientific researches and works are devoted to facilitation interaction in the "teacher-student" system, while the problem of the role of the teacherfacilitator as significant for the modern educational process has not been studied in special pedagogical studies.
Paper objective. The purpose of the study is to determine the role and functions of the teacher-facilitator for providing high quality of the educational process in modern institutions of higher education.

Paper main body. With full justification of the obtained scientific results. Until recently, pupils and students in Ukrainian schools and universities mostly received a set of knowledge without understanding how it can help them to realize themselves in life.

The large-scale changes taking place in Ukraine have primarily affected the reform of the educational system and set new requirements for education in the XXI century. It should be priority, continuous and diverse, carry humanistic values, use new learning technologies, be comprehensive and informative, and most importantly - ensure self-development of the individual. The education system, its content, and structure change with the development of society in accordance with the challenges of our time. The need for such changes is caused by certain circumstances.

First, Ukraine's entry into the humanitarian context of world civilization necessitated a radical change in the education system, methodology, and technology for organizing the educational process in various types of educational institutions, including higher education institutions.

Secondly, the formation of a manysided personality with flexible and original thinking, able to independently and creatively solve social problems, requires a constant search for new methods, organizational forms, and training technologies.

Third, there appears a real situation of competitiveness of higher education institutions.

The adoption of the framework law of Ukraine "On education" allowed the largescale reforms of the education system in Ukraine. The law defines the purpose of education as follows:

1. Comprehensive development of a human as a personality and the highest value 
ОСВIТИ ТА III ЗMICТУ

of society, his talents, intellectual, creative and physical abilities;

2. Formation of values and competencies necessary for successful selfrealization of the individual;

3. Up-bringing of responsible citizens who are capable of conscious public choice and direction of their activities for the benefit of other people and society as a whole;

4. Enriching the intellectual, economic, creative and cultural potential of the Ukrainian people, increasing the educational level of citizens to ensure the sustainable development of Ukraine and its European choice.

In General, the transformation process covers all levels of education, from primary to higher education institutions.

In the context of ongoing reforms in the system of national higher education, one of the most important tasks is to increase the level of professionalism of graduates, which is also due to the fact that with the continuous development of science and technology, the requirements for the level and quality of training of graduates are increasing. These requirements can be considered as a social order of the society in the field of education. Globalization of education also has its impact while changing the key characteristics of higher education institutions (HEI), showing new demands on them [4]. The educational process in a modern University is a complex, multi-faceted activity. The society assigned to scientific and pedagogical workers such important tasks as preserving and increasing the cultural heritage of the nation, purposeful education of the young generation, positive socialization and correct orientation of the individual at the crucial stage of its formation associated with obtaining higher professional education [4].

Of course, the HEI teacher must have the skills of an organizer, speaker, analyst, psychologist; must possess the strict logic of the pedagogical process and education, literary oral and written speech. However, the teacher must be able to speak with young people "the same language".

A modern teacher should be a highly competent specialist in his field of research, as well as an erudite in other areas of knowledge. No other profession has such a multi-faceted, detailed qualification characteristic. The teacher is not only a profession that represents transmitting knowledge, but also a high mission of creating and educating the student's personality, establishing the individual in the person. A high-quality approach to training highly qualified specialists is fully provided, provided that the teacher has the necessary knowledge in the field of pedagogy, andragogy, psychology, and infocommunication technologies, which helps to facilitate the process of communication with the audience, improve the quality of education, while the teacher's role is a priority in establishing positive relationships with the audience.

Therefore, in order to improve the quality of education in higher education institutions, it is crucial to analyze the educational process and organize effective interaction between teachers and students. Such a system of interaction assumes that it is organized on the basis of psychological and pedagogical laws. Interactive communication with students provides significant assistance in solving tasks. For example, regular surveys, testing, and questionnaires of students can help determine the effectiveness of the teacher's work, his professional qualities and communication skills, and the degree of ability to find common ground with the audience.

This approach is relevant, first of all, in the context of the introduction of updated requirements for the accreditation procedure under the "Regulations for the accreditation of educational programmes for which training of higher education seekers is carried out" [2].

In particular, the "Methodological Recommendations for the Accreditation of Educational Programmes" [3] clearly specify the criteria by which it is possible to determine the effectiveness and quality of the teacher's work, the level of academic support of applicants for higher education, the system of teaching methods used, the appropriate content of the educational component, etc.

The analysis of students' responses allows to identify gaps and shortcomings in 
the teacher's work, identify "vulnerabilities" in the educational process, and on this basis to develop measures to eliminate shortcomings, to improve the methodology of teaching disciplines, to develop measures to improve the relationship between the teacher and the student. When conducting anonymous surveys, students more sincerely express their opinions and wishes about the activities of the teacher and the educational process in general.

Since the quality of higher education institutions includes, first of all, an assessment of the quality of the educational process, it is important to determine the essence of this concept, its features and basic principles. The national education system is formed in the context of significant changes in the spiritual space of society. It requires teachers to make certain adjustments to the goals, objectives and content of the educational process. The educational process in a higher education institution for a young person is a period of not only active acquisition of knowledge related to future professional activities, but also the approval of professional priorities and preferences, and the final formation of ideological guidelines.

The Law of Ukraine "On Higher Education" defines the educational process as intellectual and creative activities in the field of higher education and science, produced in a higher educational institution (scientific institution) via the system of scientificmethodical and pedagogical activities and is aimed at the transfer, assimilation, augmentation and use of knowledge, skills and other competences of the trainees, as well as on the formation of a harmoniously developed personality (in the old edition of the law of Ukraine "On Higher Education" used the term "educational and nurturing process") [4].

The organization of the educational process in a higher education institution is carried out in accordance with the Constitution of Ukraine, the laws of Ukraine "On Higher Education", "On education", "On scientific and technical activities" and other legal acts, international agreements of Ukraine concluded in accordance with the procedure established by law, state education standards and other acts of legislation of Ukraine on education.
The result of the educational process is the formation of a set of competencies and learning outcomes acquired by the individual in the course of training on a certain educational-professional, educationalscientific program that can be identified, quantified and measured.

The quality of educational activity is determined by the level of organization of the educational process in a higher education institution that meets the standards of higher education, ensures that individuals receive quality higher education and contributes to the creation of new knowledge. Each institution of higher education in accordance with the law develops and approves the decision of the academic Council Regulations on the organization of the educational process.

The educational process can be defined as intellectual, creative activity in the field of higher education and science, which is carried out in a higher education institution (scientific institution) through a system of scientific and methodological and pedagogical activities aimed at the transfer, development, increase and use of knowledge, skills and competencies of students, as well as the formation of a harmoniously developed personality.

The essence and content of the educational process in higher education institutions in Ukraine [2, 4] have been systematized by the authors and are reflected in more detail in the table.

The educational process itself is implemented on the basis of a system of such principles: openness, accessibility, continuity, independence from interference of any political parties, public and religious organizations, unity of scientific and educational activities, etc.

In accordance with the law of Ukraine "On Higher Education", the forms of organization of the educational process in higher educational institutions are: training sessions, independent work, practical training, control activities [4].

The main types of training sessions in higher education institutions are lectures, laboratory, practical, seminars, individual classes, and consultations. 
The essence and content of the educational process in higher education institutions of Ukraine

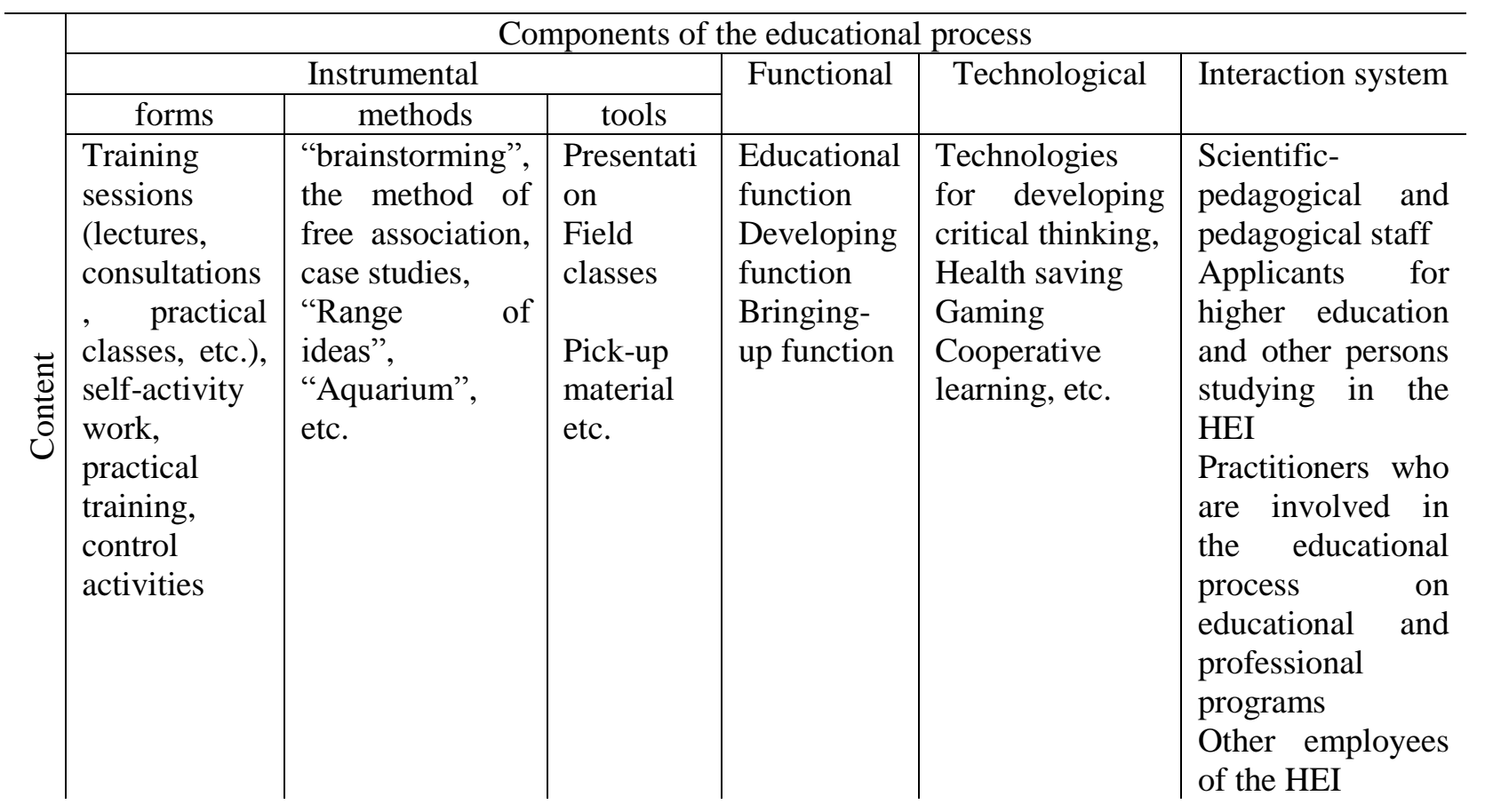

Also, the higher education institution has activity of students and attendees, aimed at the right to establish other forms of educational working out various scientific sources in process and types of training sessions. There are preparation for lectures, seminars and two main actors involved in the educational practical classes, writing essays, term papers, process in higher education institutions: teachers diploma and master's works, etc.

and students [4].

Analysis of publications psychol psychological and pedagogical research [5, 8, 9, education is its focus on professional training 10] made it possible to highlight special features of future specialists. The idea of professional in the educational process in higher education orientation of teaching all academic institutions: disciplines should be the leading one. In this

1. Each scientific discipline is studied by regard, teachers should know the specifics of students and attendees in its development and professional activities of future specialists, dynamics. The teacher should providetheir leading professional functions and information about the origin, formation and focus on them in the learning process development of a particular science, the These features provide for prospects for solving its current problems.

2. A prerequisite for the educational process in higher education institutions is its combination with scientific research. The teacher has the right to combine teaching with active research work in the field of science, which he teaches, and to encourage students and attendees to research work by his own example.

3. There is a large volume of independent educational and cognitive compliance with specific principles of the educational process, namely:

1. The principle of unity of scientific and educational activities of departments and teachers. Research work carried out at the department contributes to the improvement of the entire educational process and the development of skills of scientists and teachers. The effectiveness of teaching activity is determined by the ability of a scientist-teacher to engage students/attendees with his creativity, attract them to science, 
form their curiosity and striving for knowledge. Under such conditions, students/attendees are willing to participate in scientific conferences, discussion of scientific problems, and are violated here.

2. The principle of students' participation in research work. In the course of training, the student/attendee is given the opportunity to acquire some experience in conducting research in the specialty.

3. The principle of organic unity of theoretical and practical training of students/attendees. This principle is based on the principle of unity of theory and practice. The success of this principle depends to a large extent on the correct balance of theoretical and practical classes, which should be provided by the curricula of higher education institutions.

4. The principle of taking into account the personal capabilities of each student. When organizing the educational process, it is necessary to take into account the fact that each student/attendee is a unique person with his own abilities and capabilities. Therefore, the task of teachers is to help students/attendees discover and develop such abilities and opportunities.

A full-fledged educational process in a higher education institution should also be defined by "academic respectability". As noted by the Ukrainian teacher V. Andrushchenko, "academic respectability" as an important characteristic of European education is a fairly complex and multi-level education, which focuses on a set of moral qualities that determine the consciousness and behavior, determine the lifestyle of each of the participants in the educational process. Academic respectability is the virtue of a professor who cannot give lectures from time-yellowed notes; it is the position of a student who does not use "cribs"; it is the attitude of parents who seek to educate their children in accordance with their personal abilities and needs, and not in pursuit of the prestige of an educational institution or specialty; it is a transparent procedure for admission to a higher educational institution and many other issues that are painful for our time and our reality" [6, p.10].

All these principles are closely interrelated, they determine each other, and none of them can be used without taking into account the other. Therefore, during the educational process, it is necessary to follow all the principles. In turn, the purpose of the educational process is to prepare competent, highly qualified, competitive specialists in the national and international labor markets for the relevant industry (in the specialty of the University) and related industries or areas of public life. The effectiveness of achieving the goal of the educational process is inextricably linked to its quality.

In our opinion, the quality of the educational process in a higher education institution should be defined as a complex, substantive and procedural characteristic that consists of the following components:

- compliance of conditions with the needs of students;

- value of the content of education provided;

- compliance of scientific and pedagogical personnel;

- technological organization of the educational process;

- effectiveness of education, development of students/attendees as harmoniously developed individuals.

The essence of the educational process in higher education institutions of Ukraine is a purposeful combination of the processes of transfer and acquisition of knowledge with a mandatory selfeducational element.

In our opinion, the learning process must necessarily include such an important element as self-education. And not for nothing, since at the current stage of society's development, the need for competent specialists is being actualized, and special requirements are being set for training future specialists in the labor market (namely: communication skills, critical thinking, collaboration and interaction, self- 
ОСВIТИ ТА III ЗMICТУ

development, social responsibility, etc.). Today's society requires and needs professionals who have a flexible and original thinking. They must independently and creatively solve social problems that constantly supplement and improve professional knowledge and skills through self-education. Therefore, a specialist cannot be competitive without the formation of selfeducational competence.

In our opinion, it is in this context that it is important and relevant to consider innovative approaches to the educational process. In particular, the facilitation approach. After all, teaching as a process of presenting knowledge makes sense in a constant environment. However, we live in a dynamic environment that is constantly changing. In his system of views, C. Rogers compared the work of a teacher with the work of a therapist, who does not form a person, trying to mold him, but helps the student to find the positive in himself that is already developed in him. It is Carl Rogers who introduces the term facilitation of learning, uses this mechanism in the classroom, and considers it highly effective. "...I consider the facilitation of teaching as a process by which we can learn to live ourselves and contribute to the development of the student. I believe that the facilitating type of training provides an opportunity to be in a changing process, to try, design and find flexible answers to the most serious questions that humanity is concerned with today" [7]. Rogers wanted to escape from the name "teacher" and replace it everywhere with "facilitator", that is, such an organizer of the class, who is most interested in the needs and requests of students, who before the class thinks not about how to master all the didactic units, but how to create such a favorable atmosphere that students want to know, satisfy their intellectual, socio-cultural needs. This approach is close to us in the organization of educational process in HEI and is, in our opinion, the most productive for the formation of a highly professional and competitive modern specialist.
In general, the facilitation approach contributes to the implementation of the subject-subject paradigm of education. This approach assumes flexible use of different learning styles, cooperation of the teacher and students of the master's (postgraduate) program. The facilitation approach is the process of managing the situation and developing the existing managerial potential of the future specialist in various fields. The teacher-facilitator promotes/facilitatively accompanies the process in accordance with the dynamics of educational or personal selfregulation in difficult conditions. In the conditions of group problem solving, the facilitator activates the creative activity of future specialists of various profiles, probabilistic forecasting and search design.

In our opinion, it is appropriate to compare the principles of the facilitation approach and the approach of traditional principles of educational practice.

The principle of an absolute positive relationship versus the principle of a conditionally positive relationship. In the traditional model, the actions of students/pupils and the teacher themselves are qualified as successful only if they meet the established standards of an authoritative body. The facilitation approach model supports the right to a personal position within a collective entity.

The principle of transition "order through chaos" against the principle of gradual change. In the traditional model, pedagogical change is considered as a reverse and linear process in contrast to the transition to a higher stage of personal development through "chaos", characterized by signs of irreversibility and nonlinearity.

The principle of uncertainty versus the principle of complete determination of the educational process. The style, pace, and results of the group process are difficult to predict.

The principle of the collective subject as a common group identity, mutual involvement and distributed responsibility against the principle of individual responsibility of the subject (teacher or 
student), which claims full control in the educational process.

In the facilitative approach, it is important to identify technologies and methods that productively affect the quality of professional training of future specialists in various fields: project method, problem solving, research, portfolio method, debates, dialogues, simulation games, professional tasks, interactive learning technologies, and so on.

The use of a facilitative approach in educational practice leads to an increase in the effectiveness of group work, involvement and interest of participants, and the disclosure of their potential.

Thus, the use of facilitative approach to training future specialists in various fields contributes to the capacity development of professional identity, creates conditions for the development of facilitative competency, increases the effectiveness of their training and further professional activities. The teacher-facilitator increases the effectiveness of training, primarily by optimizing the process of working together in the "teacherstudent" and "student-student" groups. At the same time, forms and methods of internal group interaction are important: how students communicate with each other, how they find a common understanding of problems, what decisions they make, and how they resolve conflicts.

Pedagogical facilitation imposes a number of requirements both to the learning process and to the teacher's personality, especially to his ability to build relationships with students. The essence of pedagogical facilitation in professional education is to overcome the traditional assignment of performing functions to students. This will allow you to move away from the formation of a specialist functionary to the preparation of an active graduate, capable of independent analysis and making non-standard decisions.

Within the framework of pedagogical facilitation, the teacher faces the following tasks that should be solved:

- diagnostics of typical and individual problems of the audience (degree of motivation to continue education, information request, current level of professional competence and claims, readiness to study in the proposed form, psychophysiological and socio-psychological characteristics, previous educational and professional experience, etc.);

- assistance in self-determination and selection of the necessary professional and personal development educational route and training regime;

- support in adapting to learning conditions (composition of students, content, ways of working with information);

- creating conditions for a positive mood and understanding the prospects for professional and personal growth;

- the formation of a situation of intersubject interaction during the training;

- providing each student with the opportunity to express themselves and assert themselves among fellow students by presenting their own Selfhood and life experience;

- providing real developmental progress in the development of educational content in the logic of "attitudeconsciousness-activity";

- providing a specific educational product that can be "transferred" to the situation of professional activity (project, action program, technology, etc.)

- psychological assistance to get out of the situation of training and prospects for further advancement in the space of professional activity.

In the process of facilitating training, the teacher gets the opportunity to use not dogmatic methods and techniques, but those that contribute to the creative assimilation of the necessary information, form the ability to reason, look for new faces of problems in the already known material. It allows the teacher to take a position not "above", but "together" with the students and not be afraid of being accused of "ignorance of existing problems in practice", which are analyzed during the course and are often questioned.

Thus, he remains a researcher and does not lose his face as a scientist, does not 
put on the mask of a dogmatic teacher who gives unambiguous answers to all questions of the curriculum without exception. Altogether, this creates conditions for increasing students' interest and cognitive activity, and optimizes the process of developing their professional self-awareness and formation.

To master the facilitation technology, a sufficient level of development of such teacher qualities as empathy, reflection, leadership, and communication skills is required [4]. But, in addition, there must be a need for the student to master the profession, to improve the professional qualities of the individual. Key techniques and methods of facilitation communication are:

- respect and positive acceptance of the student as a person capable of selfchange and self-development;

- manifestation of pedagogical delicacy based on trust without connivance, simplicity of communication without familiarity, influence without suppression of independence, humor without ridicule;

- creating situations of success, advancing praise, addressing the learner by name.

All this is aimed at improving the system for evaluating the quality of educational results in the context of modernizing modern education. Pedagogical facilitation becomes more effective in practical application if the teacher is included in the organized innovation activity. Innovation as a characteristic of the pedagogical process refers not only to the change in the psychological figure of the teacher and the student, but also characterizes the didactic construction of the process and the ways of its organization. In the works of innovative teachers, it is shown that the active development of a student directly depends on the teacher's professional and pedagogical skills to create the appropriate emotional tone of the learning process [8]. The teacher's concerned attitude plays a key role in the context of increasing pragmatism, reduced motivation for teaching, and excessive informatization. The emotional potential of the teacher-facilitator is crucial in the education of a passionate, responsible, empathetic and creative person. Only a teacher-facilitator can resist excessive informatization and "loss of the human element in it". The principle of personal orientation of a student's education at any University in the conditions of informatization and computerization is implemented by means of facilitation communication, and the personal-activity approach itself assumes, first of all, changing the position of the teacher-informant to the position of the facilitator.

The facilitation approach, as a part of personality-oriented learning, is an effective means of humanizing and humanizing education in higher education.

One of the ways to modernize the educational system of Ukraine is to introduce innovative teaching technologies and methods into the educational process in higher education institutions ("brainstorming", the method of free associations, cases, "Range of ideas", "Aquarium", etc.). These technologies are instrumental characteristics of the facilitation approach.

Thus, developing training contributes to the development of thinking, the formation of will, emotional and sensory sphere; educational interests, motives and abilities; performs an educational function. The formation of a scientific worldview is the basis for the education of moral, labor, aesthetic and physical qualities of the individual. In the course of training, such moral qualities as a sense of duty and responsibility, friendship and collectivism, kindness and humanism, an active position on learning and life in general, as well as the qualities necessary for a future specialist in any industry are formed: ability to plan your work, select techniques for its implementation, control yourself, use time management skills in professional activities.

As noted above, one of the ways to modernize the educational system of Ukraine 
is the introduction of a facilitative approach to the educational process in higher education institutions by means of introducing innovative teaching technologies and methods, namely the use of:

- the brainstorming method, the main function of which is to teach students/attendees how to generate ideas. This method allows you to identify and compare individual judgments, consider the entire range of ideas for solving the problem, and then choose a balanced and reasonable solution from many options;

- the method of free associations that generate productive thoughts to solve the problem (to provide conditions for the emergence of free associations (for example, openness to the perception of new ideas that at first glance seem incomprehensible or paradoxical, impossible to use), to encourage students and attendees to express words and phrases that can cause the audience certain associations, etc.);

- case study method (solving practical problems), which aims to put students in a situation where they will need to make a decision;

- the "Range of ideas" method, which aims to attract all students and attendees to discuss the problem. This method is aimed at developing the ability to work in a team, to justify their own opinion;

- the "Aquarium" method, which helps to improve working skills in small groups, form a communicative culture and develop practical thinking. "Aquarium" contributes to the formation of critical thinking of students/attendees and respect for pluralism of opinions;

- the "Talk show" method, which aims to get students and attendees the skills of public speaking and discussion. Using this method, students and attendees learn to participate in general discussions, to speak concisely and argumentatively to defend their position, to influence the formation of public opinion, etc.

A special group of educational technologies is information technologies that are end-to-end, used in training, education and management.

As the role of the teacher changes, the focus, nature, and degree of facilitation will also change from level to level of impact in the following sequence: facilitation of the subject of the educational process initiates an internal need of the student and aims to provide intrinsic motivation in learning; facilitation of the subject of co-management (interaction) has the supporting character, helps keep the interest and encourages cognitive activity of students; facilitation of the teacher at self-management and interaction level is hidden, implicit, provides the conditions for independent productive activities and performs the function of supporting the development of the qualities of the individual student (self-direction, initiative and reflexivity of thinking, creativity, etc.).

Thus, the implementation of tasks in higher education institutions depends on a clear and skillful structuring of the educational process, ensuring that all its functions are performed on the basis of a facilitative approach. In this context, it is important to take into account the direction of facilitation (the nature of facilitating the process of solving educational tasks).

Conclusions of the research. The problem we have considered is relevant and significant and needs further investigation. In particular, special attention is paid to the techniques of facilitation, detailed substantiation of the mechanism of their action and influence on the student's personality.

Summarizing all of the above, we come to the conclusion that facilitation is an effective productive technology in the management of pedagogical conflicts in higher education. Its main content is embedded in such a position-utterances of the facilitator: "I will help you - I know the purpose and together we will find a way to it!".

The facilitator is a person who, didactically, competently and qualitatively ensures successful group communication of 
OСВITИ ТА III ЗMICTY

students. That is, it solves the tasks, contributing to a comfortable atmosphere and fruitful discussion. The facilitator transforms the communication process into a convenient and easy way for all participants, helps the group understand the overall purpose and maintains a positive group dynamic to achieve this goal in the discussion process, while not protecting one of the positions or parties.

So, facilitation is an effective tool, a universal technology, the mastery of which significantly improves not only the quality of

\section{Список літератури:}

1. Про освіту / Закон України від 05.09.2017 № 2145-VIII // Відомості Верховної Ради - № 38 - 39. - 2017. C. 380

2. Положення про акредитацію освітніх програм, за якими здійснюється підготовка здобувачів вищої освіти [електронний ресурс] / Наказ Міністерства освіти і науки України // - Режим доступа: https://zakon.rada.gov.ua/laws/show/z0880-19

3. Методичні рекомендації 3 акредитації освітніх програм [електронний ресурс _ - Режим доступа: https://projects.lnu.edu.ua/quaere/wp-

content/uploads/sites/6/2018/10/

4. Про вищу освіту / Закон України від 01.07.2014 № 1556-VII // Офіційний вісник України. - № 63. - 2014. - С. 7

5. Две стратегии управления развитие инновационных процессов в образовании. [електронный ресурс] / Вестник Алтайского государственного педагогического университета // - Режим доступа: http://www.uni-altai. ru/Journal/vestnik/ARHIW/N1_1999/nauch_k onf/pou.html.

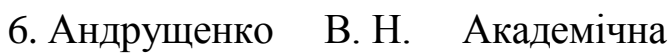
недоброчесність як виклик інтелектуальній спроможності нації / В. Н. Андрущенко // Голос України - № 132 (6887). - 2018. C. 10

7. Роджерс К., Фрейберг Д. Свобода учиться / К. Роджерс, Д. Фрейнберг // Смысл - 2002. - С. 527 mastering disciplines, but also in general professional and personal competence and productivity of students at the expense of saving time, resources, creative perspectives.

We consider prospects of the further researches in development of actual directions of activity of the modern teacher on the basis of the facilitative approach, introduction of corresponding pedagogical technologies and the organization of educational process on the basis of principles of pedagogical facilitation.

8. Татаренкова И. А., Кибец В. Н. (2015) Преподаватель как фасилитатор инновационного образовательного процесса в ВУЗе / И. А. Татаренкова, В. Н. Кибец // Современные проблемы науки и образования - № 1. - Ч.1. - С. 948 - 956

9. Димухаметов Р. С. Фасилитация в системе повышения квалификации педагогов: дис. на здобуття наук. ступеня д-ра пед. наук: спец. 13.00.08 / Р. С. Димухаметов // "Теорія та методика професійної освіти” - Магнітогорськ. 2006. - C. 350

10. Ромашина С. Я. Фасилитативная педагогика / С. Я. Ромашина // Барнаул: Азбука. - 2011. - С. 300

\section{References:}

1. "About education" (2017), Law of Ukraine dated 05.09.2017 № 2145-VIII, Verkhovna Rada Vedomosti, no. 38 - 39, p. 380

2. "Regulations on accreditation of educational programmes for which applicants for higher education are trained", Nakaz Ministerstva osvity i nauky Ukrainy, available at: https://zakon.rada.gov.ua/laws/show/z0880 $-19$

3. "Guidelines for the accreditation of educational programmes", available at: https://projects.lnu.edu.ua/quaere/wpcontent/uploads/sites/6/2018/10/

4. "About higher education" (2014), Law of Ukraine dated 01.07.2014 No. 1556VII, Ofitsijnyj visnyk Ukrainy, no. 63, p. 7 
5. "Two strategies for managing the development of innovative processes in education", Vestnik Altajskogo gosudarstvennogo pedagogicheskogo universiteta, available at: http://www.uni-altai. ru/Journal/vestnik/ARHIW/N1_1999/nauch_k onf/pou.html.

6. Andrushchenko, V. (2018), "Academic dishonesty as a challenge to the nation's intellectual capacity", Holos Ukrainy, no. 132 (6887), p. 10

7. Rogers, K., Freberg, D. (2002), "Freedom to learn", Smysl, p. 527
8. Tatarenkova, I., Kibets, V. (2015), "Lecturer as a facilitator of an innovative educational process at a university", Sovremennye problemy nauki i obrazovanija, no.1, part.1, p. $948-956$

9. Dimukhametov, R.S (2006), "Facilitation in the system of teacher training: diss. for the sciences. of dr. ped. sciences: special. 13.00.08, "Teoriia ta metodyka profesijnoi osvity", Magnitogorsk. p. 350

10. Romashina, S. Ya. (2011), "Facilitative pedagogy", Barnaul: Alphabet, p. 300

Стаття надійшла до редколегї 12.03.2020 